\title{
Kemik Dokusunun Fizyolojisi
}

\author{
Burcu İnsal $^{1}$, İksin Pişkin ${ }^{2}$ \\ ${ }^{1}$ Ankara Üniversitesi Veteriner Fakültesi Anatomi Anabilim Dall, Ankara \\ ${ }^{2}$ Ankara Üniversitesi Veteriner Fakültesi Fizyoloji Anabilim Dall, Ankara
}

\begin{abstract}
Özet: Kemikler, hücreler arası sıvısı sert ve kalsifiye olmuş bir çatı tarafından kuşatılmış, osteoblast, osteosit ve osteoklast denilen özel hücreler tarafından meydana getirilir. Bu hücreler, hormonlar, sitokinler, büyüme faktörleri gibi yerel sinyalizasyon faktörlerinin etkisi ile farklı şekillerde bir araya gelerek kemiğin oluşumu ve büyümesini sağlarlar. Osteoblastlar, doku matriksinde kalsiyum tuzlarının birikmesiyle ossifikasyonu şekillendirir. Kemik dokunun fizyolojik ve mekanik değişimler karşısında gösterdiği tepki modellenme (modeling), normal kemik yapısının korunması ve bu değişikliklere karşı gelişen adaptasyonu ise yeniden şekillenme (remodeling) ile açıklanır. Canlı vücudunda üstlendiği görevler ve sahip olduğu özellikleri sebebiyle canlıda hem genel yapının korunması hem de meydana gelebilecek bozuklukların giderilmesi konusunda kemik dokusunun fizyolojisinin bilinmesi büyük önem taşır. Bu nedenle bu derlemede kemik dokusunun fizyolojik işlevi, yapısı, oluşumu ve büyümesi hakkında bilgilere yer verilmiştir.
\end{abstract}

Anahtar Kelimeler: Kemik büyümesi, kemik doku, modelleme, ossifikasyon, yeniden şekillenme

\section{Physiology of Bone Tissue}

\begin{abstract}
Bones are formed by the combination of special cells called osteoblast, osteocyte and osteoclast which are surrounded by a rigid and calcified roof of intercellular fluid. These cells league together in different manners with local signalization factors such as hormones, cytokines, growth factors, and provide the formation and growth of the bone. Osteoblasts form the ossification via accumulation of calcium salts in the tissue matrix. The response of bone tissue to physiological and mechanical changes is modeling, the preservation of normal bone structure and adaptation to these changes are explained by remodeling. Due to the tasks of bone tissue in the body and the features it possesses, it is very important to know the physiology of the bone tissue in order to both protect the general structure and eliminate the pathological disorders that may occur in the living body. For this reason, this review includes information in the matter of the physiological function, structure, formation and metabolism of bone tissue.
\end{abstract}

Key Words: Bone growth, bone tissue, modeling, ossification, remodeling

\section{Giriş}

Kemik doku, hücreler arası sıvısı sert ve kalsifiye olmuş bir çatı tarafindan kuşatılmış birçok mekanik ve fizyolojik işlevi olan hücresel yapıdır. Kemikler, kıkırdak, ligamentler ve bağ doku ile kan damarları, lenf damarları ve sinirler bir araya gelerek iskelet sistemini oluştururlar. İskelet sistemi ve kemik dokunun vücutta oldukça önemli fizyolojik işlevleri vardır $[1,3,24]$.

Kemik dokunun en önemli fonksiyonu iskeletin hareketi ve vital organların korunabilmesi için gerekli olan sertliği sağlamaktır. Kemik dokunun diğer önemli işlevleri arasında; vücuda hareket yeteneği ve destek sağlamak, kan hücrelerinin oluşumu (hematopoesis) ve kana verilmesini sağlamak, yaygın organ disfonksiyonlarında asit-baz dengesini ayarlamak için tampon madde sağlamak, kalsiyum ve fosfor gibi mineral maddeler, büyüme faktörleri ve sitokinler için depo görevi üstlenmek sayılabilir $[2,3,6,16]$. Hastalığa maruz kalındığında kemik doku kendi kendini onarabilir ve değişen stres faktörlerine uyum gösterebilir $[8,9]$.

Taze kemik ortalama \% 25 su, \% 30 organik madde ve \% 45 inorganik maddeden oluşur [13, 24]. Organik matriks kemiğin kuru ağırlığının \% 30-35' ini oluşturur. Bunun da \% 90-95' i su bazlı solüsyonlarla kaynatılınca jelatine dönüşebilen Tip I Kollajen formundadır. Kollajen olmayan önemli organik maddeler arasinda ise, kondroitin sülfat, keratan sülfat, hiyaluronik asit, gibi glikozaminoglikanlar, osteonektin, osteokalsin, osteopontin, kemik sialoproteini gibi glikoproteinler, interlökin 1 ve 6 gibi sitokinler ile dönüştürücü büyüme faktör $\beta$ ailesi (TGF- $\beta$ ), koloni uyarıcı faktörler, trombosit kaynaklı büyüme faktörü, insülin benzeri büyüme faktörü 1 ve 2 gibi büyüme faktörleri bulunur [5, $10]$. 
İnorganik matriks kemiğin kuru ağırlığının \% 65 ' ini oluşturur. Bunun da \%95' ini hidroksiapatit $(\mathrm{Ca} 10(\mathrm{PO} 4) 6(\mathrm{OH}) 2)$ kristalleri şeklinde bulunan kalsiyum ve fosfor iyonları oluşturmaktadır. Diğer iyonlar ise; magnezyum, sodyum, potasyum ve florürdür $[3,5,6,13]$.

Kemiğin mikroskobik yapısı ise osteoblast ve osteosit denilen destek hücreleri ile osteoklast denilen ve kemiğin yeniden şekillenmesinden sorumlu hücrelerden oluşur [13].

Bir kemiğin en temel birimi osteondur. Kemiğin boyuna paralel uzanan merkezsel kanallara "Havers kanalları" denir. Bu kanalların etrafını eşmerkezli (konsantrik) dairesel lameller sarar [3,6]. Lameller üzerinde osteositlerin yerleşmesi için daha geniş bir yüzey alanı oluşturan ve lakuna denilen boşluklar yer alır [5, 24].

Havers kanal1, eşmerkezli dairesel lameller ve osteositlerden oluşan bu sisteme "osteon" veya "Havers sistemi" denir. Her bir osteon, osteon kalıntısı şeklindeki ara lameller tarafindan ayrılır [3, 6]. Havers Kanalları içinde, osteositler için gerekli olan, kemiğin diş yüzündeki ve kemik iliğindeki kan damarlarıyla bağlantılı, kan damarları (osteonal arter), lenf damarlar1 ve sinirler bulunur. Kemiğin boyuna dik uzanan damarlar ise Wolkman kanalları denilen boşluklara yerleşmiştir. Kemik içinde kanalikuli denilen dallanmış ince kanalcıklar vardır. Osteositler birbirleriyle bu kanalciklar ağ ğılla bağlantı kurarlar. Osteositlerin hücreler arası sivis1, lakunalarda ve kanalikulilerde bulunur. $\mathrm{Bu}$ sıvı kan damarlarından kanalikuliler içine yayılarak osteositlerin yaşamasını sağlar. Bu sıvının iletiminin osteositlerin periyodik kasılımları ile sağlandığ 1 düşünülmektedir [2, 15, 21, 24]. Osteositler her bir Havers sisteminin bağlantı bölgelerindeki tabakalara radial şekilde yerleşmiştir. Bir kesit alındığında, bu tabakalar bir ağacın büyüme halkaları gibi görünür $[2,5]$. Eşmerkezli dairesel lameller ile ara lamellerden başka bir de iç ve diş dairesel lameller vardır. Bunlar kemiğin enine büyümesi sırasında osteblastlar tarafindan oluşturulur böylece kemiğin iç ve dış yüzünü kaplar [5]. Bu sırada Havers sistemi de geliştiği için iç ve diş dairesel lamellerin Havers sistemine bakan yüzlerinde kesintili bir görünüm oluşur. D1ş yüzlerinde böyle kesintili bir yap1 olmadığ 1 için bu yüzeyleri pürüzsüz bir görünüme sahiptir [24].

\section{Kemik Oluşumu (Ossifikasyon, Osteogenesis)}

Ossifikasyon, osteoblastlar tarafından kemiğin şekillendirilmesi işlemidir. Diğer bir deyişle ossifikasyon, osteoblastlar tarafindan salgilanan osteoid doku matriksinde kalsiyum, fosfor ve diğer mineral maddelerin birikmesiyle gerçek kemik oluşumudur. Kalsifikasyon ise bazı dokularda kalsiyum tuzlar1nın birikimi olarak tanımlanır $[1,8,20]$. Temel olarak üç tip ossifikasyon çeşidi vardır [9].

İntramebranöz ossifikasyonda kemik gelişimi fibröz membranlardan olur. Birçok yassı kemik, kafatasındaki bazı kemikler, mandibula ve klavikula [13] fibröz membranlardan veya osteoid dokuyla ilintili matriksten şekillenir [8]. İntramembranöz ossifikasyonda, mezenşimal hücreler, kemiği oluşturmak için bir şablon oluşturmak üzere kümelenir ve bir osifikasyon merkezi oluşturur. Sonra bu hücreler, osteoblastlara farklılaşır. Osteoblastlar, matriksi sertleştirmek üzere hücre dışı bileşenleri ve osteotidi salg1lar. Daha sonra kemik benzeri osteoid doku asıl kemiği oluşturmak üzere kalsifiye olur. Son olarak periosteum şekillenir. Bundan sonra kemiğin devamı ise, kemiğin her iki yanından başlayarak periost tabakalarından oluşturulur (Şekil.1) $[9,13,21]$.

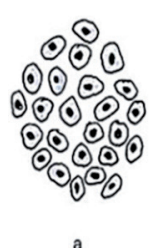

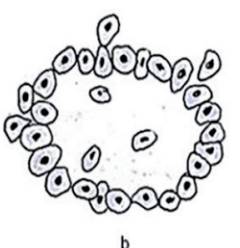

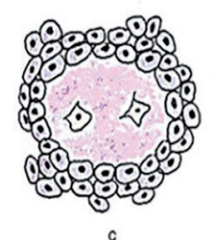

$c$

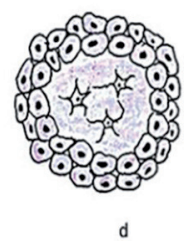

Şekil 1. İntramembranöz Ossifikasyon [13].

a. Mezenşimal hücre agregasyonu. b. Ossifikasyon merkezinin oluşumu. c. Osteoblastlar tarafindan osteoid oluşumu. d. Osteoidin kalsifikasyonu ve osteoblastların osteosite dönüşümü.

Endokondral ossifikasyonda kemik gelişimi hyalin k1kırdaktan olur. Organizmadaki iskelet sistemini oluşturan, yassı kemikler, kafatası kemikleri, mandibula ve klavikulalar hariç çoğu kemik tamamen endokondral ossifikasyonla şekillenmektedir $[1,17,21]$. Embriyoda fertilizasyondan sonra ossifikasyonun başlama süresi hayvan türlerine göre farkl1l1k gösterir. Bu süreden önce, fibröz membranlar ve hyalin kıkırdaktan oluşan embriyonik iskelette aksiyel ve apendiküler iskeletin neredeyse tamamı endokondral ossifikasyon ile gelişirken, kraniyofasiyal iskelet ise doğrudan intramembranöz 
ossifikasyon ile gelişir [22]. Endokondral ossifikasyon fetusta gerçekleşir ancak doğumdan sonra da, metafiz ve epifiz arasında bulunan kıkırdak tabakadan ve korteksi saran perikondriyumdan devam eder. Doğumdan sonraki dönemde uzun kemiklerin çoğu bu şekilde gelişir [24]. Endokondral ossifikasyonda, mezenşimal hücrelerin göçü ve kümeleşmesi (Şekil.2.a) intramembranöz ossifikasyona benzer. Ancak, bu hücreler farklı olarak kıkırdak matriksi yapacak ve osteoblastların yerine geçecek olan kondrablastlara dönüşür [1]. Uzun, kisa ve düzensiz kemiklerin embriyonik modelleri, ilk olarak, yoğun fibröz bağ doku kütlesidir. Mezenşimal kök hücrelerden farklılaşan kondrositler bu fibröz bağ doku modeliyle yer değiştirip hyalin kıkırdak matriksi kalıbını (Şekil.2.b) oluşturmaya başlar. Uzun kemiğin orta bölgesinde (diafizin merkezinde), gelişen bu kemikleşme merkezine "primer ossifikasyon merkezi” denir (Şekil.2.c). Daha sonra uzun kemiklerin uçlarına yakın kısımlarda (epifiz) gelişen ossifikasyon merkezlerine ise "sekonder ossifikasyon merkezleri” denir (Şekil.2.e) [8, 17]. Bu tür bölgelerde bir taraftan perikondriyumdaki mezenșimal kök hücreler osteoblastlara farklılaşırken, bir taraftan da kompleks gelişimsel sinyallerle, matrikste hipertrofik kondrositler de farklılaşır ve kalsifikasyon başlar [22]. Bu kalsifikasyon, matriks içinden besinlerin difüzyonunu engeller, bunun sonuncunda kondrositler ölür. Böylece osteblast, osteoklast ve daha sona kemik iliğini şekillendirecek olan hematopoetik hücrelerin öncüllerini taşıyan kan damarlarının bölgeye penetre olmasına izin verecek şekilde, diafiz üzerinde kaviteler (boşluklar) açılır (Şekil.2) $[1,13]$.
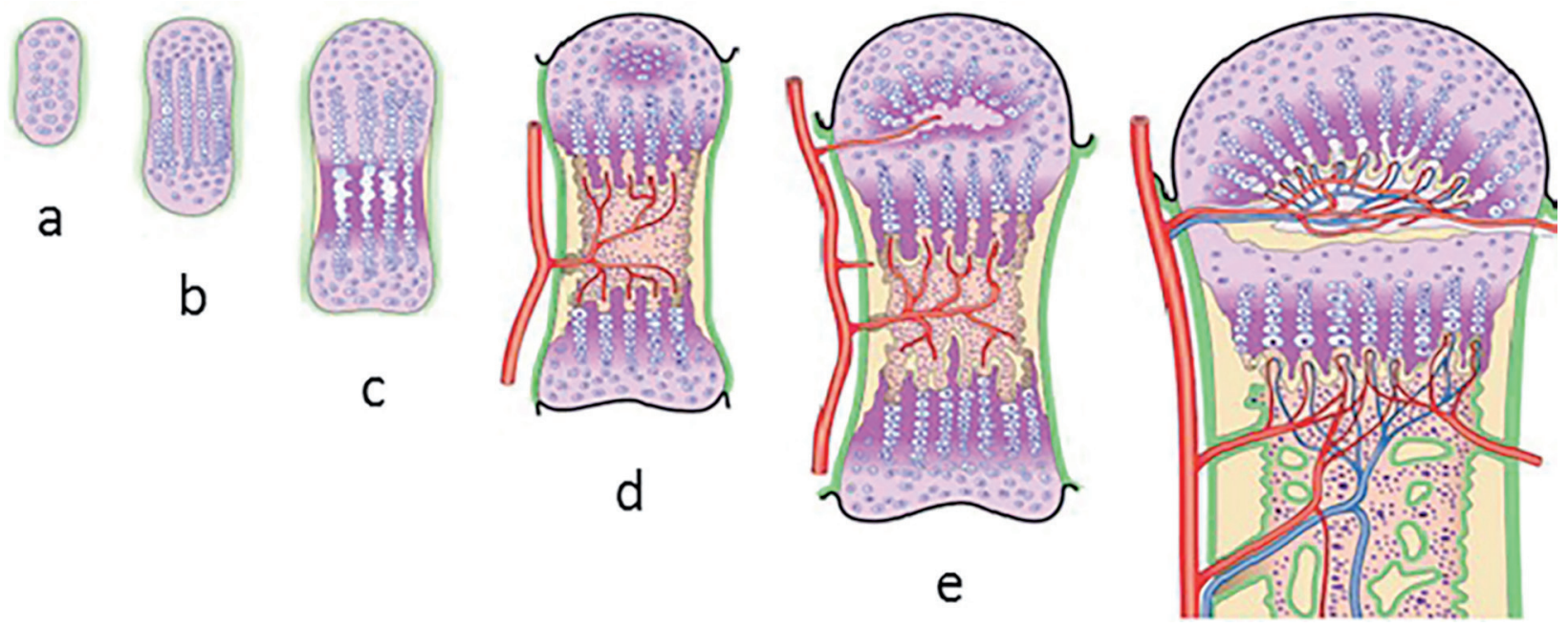

Şekil 2. Endokonral Ossifikasyon (Adams'ın çiziminden uyarlanmıştır) [21].

a. Osteoprojenitör hücre agregasyonu. b. Hyalin kıkırdak kalıbının oluşumu. c. Primer ossifikasyon merkezinin oluşumu. d. Kan damarlarının penetrasyonu. e. Sekonder ossifikasyon merkezlerinin oluşumu. f. Gelişmiş tam bir kemik yapı.

Osteoblast ve osteoklastlar kalsifiye kikırdak matriksini süngerimsi kemiğe dönüştürürken, kan damarları bu boşluklardan içeri akın ederler. Sonra osteoklastlar süngerimsi kemiğin bir kısmını, diafiz içinde, kemik iliği veya medullar kavitenin oluşmas1 için bozar Ardından kemiğin çevresinde, yoğun, düzensiz, bağ dokudan bir periosteum şekillenir. $\mathrm{Bu}$ şekilde birkaç farklı ossifikasyon merkezi genişleyip yayılır ve en sonunda, periosteuma sahip, spongiyöz kemiği olan ve içindeki boşlukta kemik iliği bulunan tam bir kemik yapı (Şekil.2.f) olgunlaşır $[13,21]$.
Heteroplastik ossifikasyon ise iskelet sistemi dışında herhangi bir doku içinde gerçekleşen kemikleșmedir. Bu tür kemikleșmeye bazı hayvanlardaki os penis ve sığır kalbindeki ossa cordis oluşumu örnektir $[13,24]$.

\section{Kemik Büyümesi}

Kemik büyümesi canlının içinde bulunduğu fizyolojik süreç göz önünde bulundurulmak üzere iki farklı şekilde açıklanır. Kemiklerin yaşam boyu fizyolojik etkilere ve biyomekanik kuvvetlere karşı kademeli olarak gösterdiği tepki sonucu şekil değiştirmesi 
"modellenme" (şekillenme, modeling) olarak tanımlanır [6, 13]. Fötal yaşamda iskelet oluştuktan sonraki dönemden itibaren tüm yetişkinlik boyunca, normal yapının korunması ile eski ve mikro düzeyde hasar gören kemiklerin uzaklaştırılması ve yerine yenisinin yapılması için kemik dokuda yıkım ve yapım olaylarının dengeli bir şekilde devam etmesi durumu ise "yeniden şekillenme" (remodeling) olarak adlandırılır [7, 13, 19]. Erişkinlikten önceki dönemde kemik büyümesi, metabolik aktivitenin yıkımdan daha çok yapım tarafında kalmasının sonucudur. Yetişkinlerde normal kemik yapının deva$\mathrm{m}$ için osteoklastik ve osteoblastik aktivite denge halinde olmalıdır [7].

Modellenme işleminin bir parçası olan kemiğin boyuna büyümesi, epifiz plağında gerçekleşir. Boyuna büyüme, kıkırdağın interstisyel büyümesi ve alttan kemik dokunun endokondral yolla eklenmesi ile sağlanır. Kemiğin çapındaki büyüme (enine kalınlaşma) ise periosteumdaki osteoblastik aktivite ve apozisyonel mekanizma (mevcut kemik dokusu üzerine depolanma) sayesinde, periosteumun altına yeni kemik eklenmesiyle sağlanır $[6,21$, 24]. Periosteum, osteojenik tabakayı sağlar ve tekrarlayan üremeler ile oluşan kemik doku, kemiğin boyuna uzaması sırasında oluşan Havers sistemleri arasındaki boşlukları doldurur. Aynı apozisyonel büyüme süreci endosteum kaynaklı olarak kemiğin gövdesinin iç yüzünde de gerçekleşir. Periosteum ve endosteumdan kaynaklanan kemik doku iç ve diş dairesel lamelleri oluşturur [24].

Gelişme çağında meydana gelen kemik modellenmesi ve erişkin çağda başlayıp yaşam boyu devam eden yeniden şekillenme olayları osteoblastların ve osteoklastların eşgüdümlü olarak çalışmaları ile olur $[14,16]$. Yetişkin olgun bir iskelette kemikler yılda yaklaşık \%10 oranında kayba uğrar, buna rağmen total hacim sabittir [3]. Yeniden şekillenme iki temel hücre aktivitesiyle sağlanmaktadır. Osteoblastlar, osteoblastik osteoid oluşumu ile yeni kemik matriksini salgılarken, dalak ve karaciğerdeki projenitör hücrelerden türeyen osteoklast öncülleri ise yeni oluşan trabeküller arasındaki kan damarlarından çekilerek "osteoklast delgisi (cutting cone)" denilen kemik yıkımını sağlar [3, 4]. Kararlı durumdaki bir kemikte osteoblastik ve osteoklastik aktivite denge halinde olmalıdır. Aksi takdirde, inflamasyonlar büyüme faktörleri ve hormonlarda- ki değişikliklere bağlı olarak gelișen osteoklast ve osteoblast aktiviteleri arasındaki dengesizlikler, kemik kütlesinin artması (osteopetroz) veya azalması (osteoporoz) ile karakterize iskelet anormalliklerine sebep olabilir [14].

Kemiğin yeniden şekillenmesi birbirini izleyen aşamalardan oluşan bir döngü şeklindedir $[3,11$, 19]. Bu döngü, osteoklastların, RANKL (receptor activator of NF-KB ligand), osteoprotegrin (OPG), IL-1, IL-6, M-CSF (monosit colony-stimulating factor), paratiroid hormon, 1,25-dihidroksivitamin D ve kalsitonin tarafından uyarılmasıyla gerçekleşir (Şekil.3) [6].

Sessiz (sakin) bir kemikte aktivasyon işlemi, kemik iliğindeki öncül hücrelerin, kemikten ayrılıp çok çekirdekli, dirençli ve kemik yüzeylerine tutunan osteoklastlara farklılaşmasıyla başlar. Yeniden modellenmenin bu ilk aşaması "sakin dönem" olarak adlandirilır [3, 23].

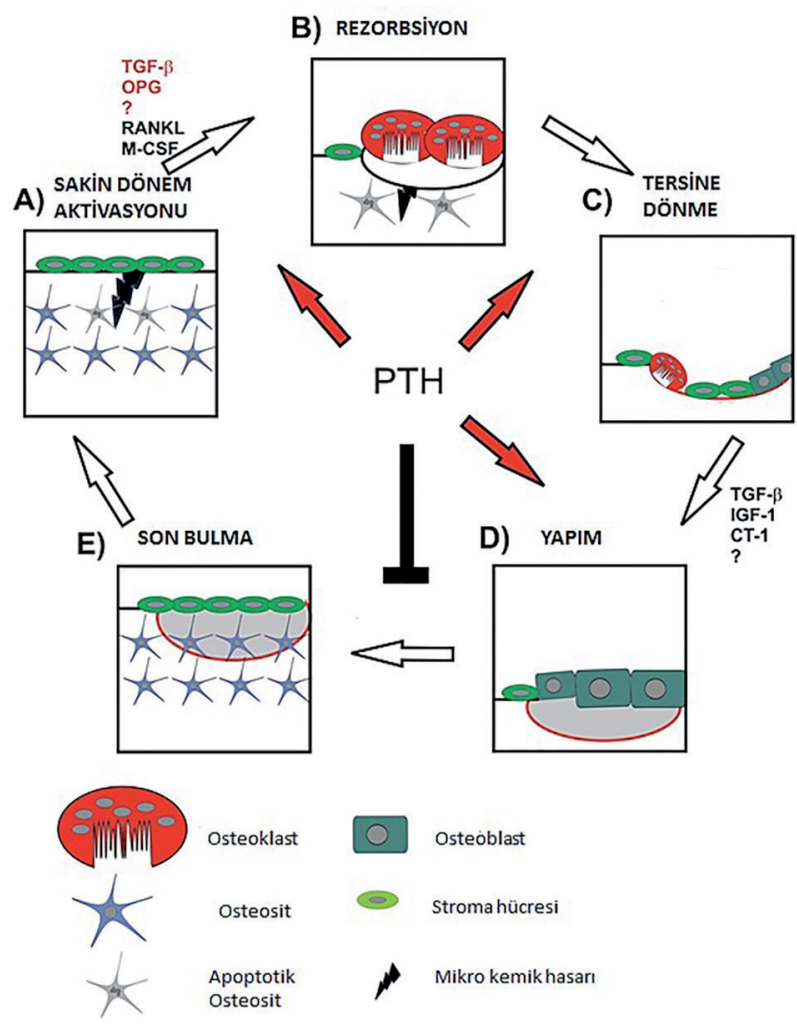

Şekil 3. Kemiğin yeniden şekillenme döngüsü [11].

Ardından yerel sitokinler ve hormonların etkisiyle osteoklastik aktivite artar ve "rezorbsiyon dönemi" başlar [3, 10]. Osteoklastlar trabeküler kemiğin yüzeyine tutunurlar. Kemiğin organik mat- 
riksi osteoklastlar tarafindan salgılanan lizozomal enzimler olan hidrojen fosfataz, kollajenaz ve diğer proteolitik enzimlerle yıkımlanır ve hidrojen iyon salınımının (düşük pH' da matriks kristal içeriği bozulur) bir sonucu olarak mineral matriks azalır. $\mathrm{Bu}$ aşama yaklaşık 2 hafta kadar sürer [3, 10, 18, 19 ]. Kemik matriksinin yıkımlanmasıyla kemik matriksi içinde düzensiz yapıda Howship boşlukları ve Havers kanalları şekillenir. Bu kavitelere gelmek üzere kendi öncül hücrelerinden gelişen osteoblastlar aktive edilir. Aktive olan osteoblastlar, kemik yıkımlanması sonucu açığa çıkan sitokinlerin salg1landığ 1 bölgelerde toplanırlar. $\mathrm{Bu}$ aşamadan sonra artık osteoblastik aktivite yani kemik yapımı başlar ki bu aşamaya ise "tersine dönme" denir [3, 19]. $\mathrm{Bu}$ evre osteoklastların apoptozisi ile sonuçlanır. $\mathrm{Bu}$ aşamanın ardından mezenşimal öncüllerinden farklılaşan osteoblastların, mineralizasyonu kontrol etmek ve organik matriks olușturmak üzere, osteoid sentezleyerek yeni kemik dokusunun oluşmasını sağladığı dönem olan "yapım dönemi” başlar [3, 19]. Kemik yapımının tamamlanması yaklaşık 4-6 ay alır [6]. Osteositler tarafından kontrol edilen, bütün işlemlerin sonlandığ 1 ve normal bir kemik formunun tamamen şekillendiği dönem ise "son bulma" olarak adlandırılır $[3,11,18]$.

Kemiklerin yeniden şekillenmesinin moleküler kontrolü yaygın olarak çalışılmıştır ve sistemik düzenlenmenin, başta paratiroid hormon ve kalsitriol olmak üzere, büyüme hormonu, glikokortikoidler, tiroid hormonlar1, prolaktin ve cinsiyet hormonları gibi hormonlar, yerel faktörler ve sitokinler tarafından kontrol edildiği iyi bilinmektedir $[10,14,16$, 19]. Henriksen ve ark. na [11] göre, son zamanlardaki yapılan çalışmalar, kemiğin yeniden şekillenmesinde, daha az bilinen ve oldukça önemli olan yerel sinyalizasyonun, kemik hücreleri arasında doğrudan oluştuğunu göstermektedir. Buna ek olarak, yerel kemik hücreleri arasındaki sinyalizasyon gibi, sempatik sinir sistemi, immun sistem, hematopoetik kök hücreler, damarlar ve hatta eklem kıkırdağının hücreleri de kemik yapımını kontrol eder [12, 19].

\section{Kaynaklar}

1. Akers RM, Denbow DM, (2008). Anatomy and physiology of domestic animals. First edition. p. 133-143.

2. Bassert JM, Colville T, (2002). Clinical anatomy and physiology for veterinary technicians. p. 95-118.
3. Bayliss L, Mahoney DJ, Monk P, (2012). Normal bone physiology, remodeling and its hormonal regulation. Surgery. 30(2), 47-53.

4. Boyce BF, Xing L, (2008). Functions of RANKL/RANK/ OPG in bone modeling and remodeling. Arch Biochem Biophys. 473.139-146

5. Buckwalter JA, Glimcher MJ, Cooper RR, Recker R, (2010). Bone biology. J Bone Joint Surg Am. 77.1256-1275.

6. Clarke B, (2008). Normal bone anatomy and physiology. Clin J Am Soc Nephrol. 3. 131-139.

7. Çayır F, (2011). Osseointegrasyon. Doktora Tezi. EÜ Diş Hekimliği Fakültesi, İzmir.

8. Fails AD, Fradson RD, Wilke WL, (2009). Anatomy and physiology of farm animals. Seventh edition. p.59-85.

9. Fradson RD, Spurgeon TL, (1992). Anatomy and Physiology of Farm Animals. Fifth edition. p. 55-81.

10. Hadjidakis JD, Androulakis II, (2006). Bone remodeling. Ann NY Acad Sci 1092. 385-396

11. Henriksen K, Neutzsky-WulffAAV, Bonewald LF, KarsdaL MA, (2009). Local communication on and within bone controls bone remodeling. Bone. 44. 1026-33

12. Iain HK, (2001). Principles of bone healing. Neurosurg Focus 10(4). 1-4.

13. Kini U, Nandeesh BN, (2012). Physiology of bone formation, remodeling, and metabolism. Fogelman I. et al. eds. Radionuclide and Hybrid Bone Imaging. Springer Press. Berlin-Heidelberg p.30-55.

14. Kong YY, William JB, Penninger MJ, (2010). Osteoprotegerin ligand: a regulator of immune responses and bone physiology. Immunol Today. 21(10). 495-502.

15. Lanyon LE, (1993). Osteocytes, strain detection, bone modeling and remodeling. Calcif Tissue Int. 53. 102-107.

16. Leibbrandt A, Penninger JM, (2008). RANK/RANKL: Regulators of immune responses and bone physiology. Ann NY Acad Sci. 1143. 123-150.

17. Mackie EJ, Ahmed YA, Tatarczuch L, Chen KS, Mirams M, (2007). Endochondral ossification: How cartilage is converted into bone in the developing skeleton. J Biocel. 40. 46-62.

18. Raggatt LJ, Partridge NC, (2010). Cellular and molecular mechanisms of bone remodeling. JBC Papers. 285. 2510325108.

19. Raisz LG, (1999). Physiology and pathophysiology of bone remodeling. Clin Chem. 45(8). 1353-1358.

20. Rauch F, Schoenau E, (2002). Skeletal development in premature infants: a review of bone physiology beyond nutritional aspects. Arch Dis Child Fetal Neonatal Ed. 86. 82-85.

21. Standring S. (2016). Gray's anatomy: The anatomical basis of clinical practice. Forty-first edition. Elsevier press. p. 81-123.

22. Vortkampa A, Pathia S, Perettib GM, Enzo M. Carusob EM, David J. Zaleskeb DJ, Tabin CJ, (1998). Recapitulation of signals regulating embryonic bone formation during postnatal growth and in fracture repair. Mech Dev. 71. 65-76.

23. Watts NB, (1999). Clinical utility of biochemical markers of bone remodeling. Clin Chem. 45(8). 1359-1368.

24. William OR. (2009). Functional anatomy and physiology of domestic animals. Fourth edition. p. 179-198. 